\title{
Learning how to learn: The role of music and other expressive arts in responding to Early Leaving from Education and Training (ELET) in the STALWARTS project
}

\author{
Viggo Krüger ${ }^{12}{ }^{*}$, Eunice Macedo ${ }^{3}$, Anna Rita Addessi ${ }^{4}$, Eha Rüütel ${ }^{5}$, Catherine Warner $^{6}$, \\ Alexandra Carvalho ${ }^{7}$, Leslie Bunt ${ }^{8}$ \\ 1 NORCE Norwegian Research Centre, Norway \\ 2 University of Bergen, Grieg Academy, Norway \\ 3 University of Porto, Faculty of Psychology and Educational Sciences, Centre for Research and \\ Intervention in Education, Porto, Portugal \\ 4 University of Bologna, Italy \\ 5 Tallinn University, Estonia \\ 6 University of the West of England, Faculty of Health and Applied Science, Department of Health and \\ Social Sciences, Bristol, UK \\ 7 University of Porto, Faculty of Psychology and Educational Sciences, Centre for Research and \\ Intervention in Education, Porto, Portugal \\ 8 University of the West of England, Faculty of Health and Applied Science, Department of Health and \\ Social Sciences, Bristol, UK \\ *viggo.kruger@uib.no
}

Received: 8 March 2020 Accepted: 8 May 2020 Published: 1 November 2020

Editor: Michael Viega Reviewer: Rebecca Fairchild

\begin{abstract}
This project report describes policy, practice and theory related to a cross-sectoral international project funded by the European Union's Erasmus+ programme. STALWARTS- Sustaining Teachers and Learners with the Arts: Relational Health in European Schools-aimed to promote relational health in schools through engagement with the arts. The project was developed in five European countries: Estonia, Italy, Norway, Portugal, and the UK. The local partnerships between five universities and community-based schools are diverse in terms of their locations in the European region and the populations they serve, in terms of age, social status and learning conditions.

In this article we focus on the link between ELET policies in each country and local context. We ask: How can identified ELET policy initiatives in the five partner countries relate to the achievements of the STALWARTS partner schools when working with the expressive arts? Some related theoretical background underpinning the practical aspects of the project brings this report to a conclusion.
\end{abstract}

Keywords: School, Education, ELET, Music, Music therapy, Expressive arts, Inter- 


\section{Introduction}

Every child has the right to go to school and learn in safe and motivating environments. However, finishing education is not always the case for children, and the consequences related to dropping out of school are linked to unemployment, social exclusion, and poverty (Munro, 2011). Poor educational achievement is often seen as a potential generator for marginalisation, creating a foundation for exclusion from the labour market, and poor health and social problems in the knowledge economy (Vinnerljung \& Sallnäs, 2008). With these concerns the Erasmus + funded project STALWARTS-Sustaining Teachers and Learners with the Arts: Relational Health in European School-aimed to promote relational health in schools through engagement with arts. Erasmus + is the European Union programme for education, training, youth and sport (2014-2020; for further information see Erasmus +, 2020). The grant for STALWARTS was part of the support for higher education projects.

The project was developed in five European countries: Estonia, Italy, Norway, Portugal, and the UK. The five universities and five partners, community-based schools, are diverse in terms of their locations in the European region and the populations they serve, in terms of age, social status and learning conditions. This allowed for promoting further inclusion of the creative arts as an educational strategy to contribute to combating Early Leaving from Education and Training (ELET) in the different contexts of learning. The project aimed to build on the relational dimensions of learning that we describe as relational health in education. STALWARTS complemented and built upon the achievements of the earlier European Union's Erasmus + funded project LINK (Learning in a New Key) through facilitating collaboration and learning between students, teachers, educators, researchers and music and other creative arts therapists, with a special attention towards music.

Some of the main objectives of STALWARTS were to:

1. transform the learning experiences gained from LINK into commonly accredited professional programmes of study recognised within the administrative systems of the five partner universities;

2. prepare music/arts-based therapists and trainers as teachers in these new programmes of study in the participating countries;

3. engage teachers in classroom-based music- and arts-based trainings that lead to their enrolment in these new accredited study programmes as a means to tackling ELET; and

4. develop more understanding of the links between theoretical and practical elements of arts-based therapeutic teaching practices, with reference to neuroscience knowledge and to the needs of young people with adverse childhood experiences (Felitti \& Anda, 2010).

With these objectives in mind we continue with some further notes on ELET as an individual and social problem (Araújo et al., 2019; European Commission, 2011). To provide a wider understanding of the contexts where the inter-professional learning was developed, another section follows that briefly presents the diverse universities and schools involved in the project and their contributions to the struggle for a relational, holistic and inclusive practice that reengages young people with learning. We include in an Appendix some of the policies dealing with ELET that set out the different five national frameworks, with further information contained in the references (see Appendix).

In this report we focus on the link between ELET policies in each country and each local context, and ask: How can identified ELET policy initiatives in the five partner countries relate to the achievements of the STALWARTS partner schools when working with the expressive arts? Some related theoretical background underpinning the practical aspects of the project brings this report to a conclusion. 


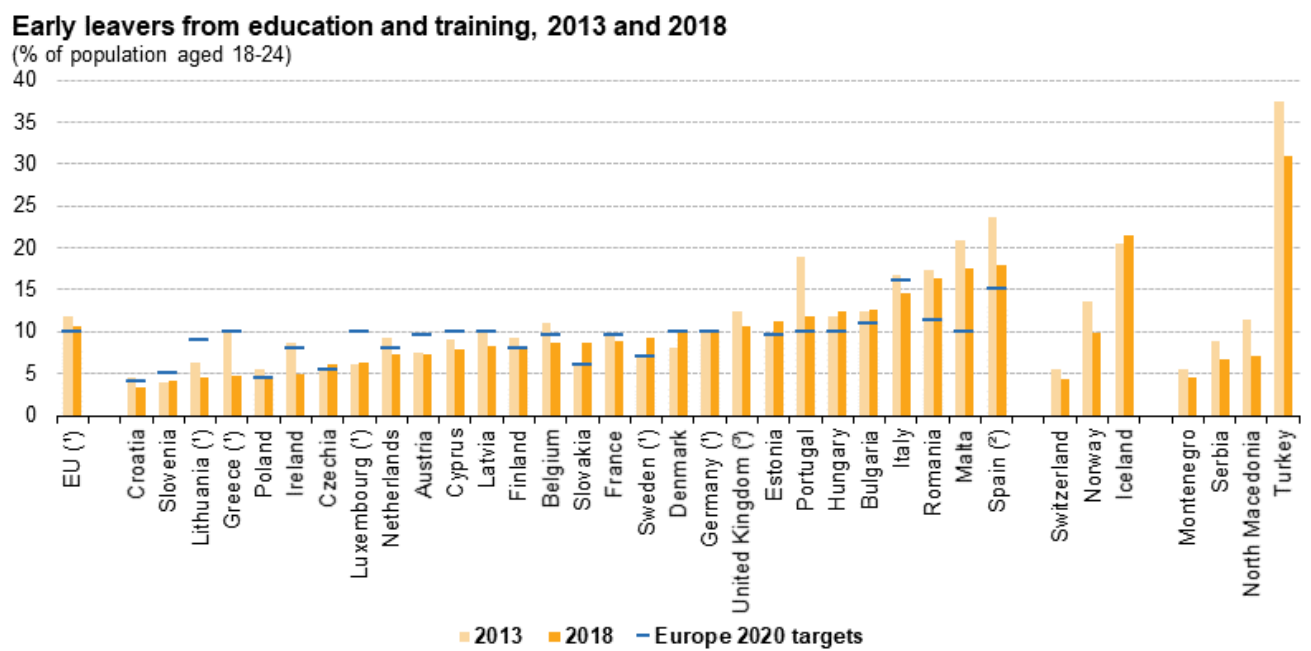

Note: breaks in series.

(') For the target to be achieved, the share of early leavers from education and training should be below the target value.

(2) Europe 2020 target is defined as the school drop-out rate

(3) No Europe 2020 target.

Source: Eurostat (online data code: edat_lfse_14)

eurostat?

Figure 1

Early leavers from education and training (\% of population aged 18-24; Eurostat, 2019)

\section{Further notes on ELET}

ELET refers to young people aged 18 to 24 who have completed at most a lower secondary education and are not in further education or training. The struggle against early leaving has been a priority for the EU since 2000 as part of the Lisbon Strategy. The objective was to reduce the share of early leavers to $10 \%$ by 2020 . In 2019 , an average of $10.6 \%$ of young people (aged 18-24) in the EU-28 were early leavers from education and training (Eurostat, 2019).

According to Eurostat (2019), the overall share of ELET fell in the EU-28 by $1.3 \%$ between 2013 and 2018. In this same period the countries involved in STALWARTS decreased their averages, except for Estonia, which increased 1.6\% but is still near the EU average of $11.8 \%$. In 2018 , Norway already reached a value below the challenge for 2020 (9.9\%), having decreased the rate of ELET by 3.8\%. Portugal registered a decrease of $7.1 \%$, with an average of $11.8 \%$, in 2018. In the same year, the UK registered an average of $10.7 \%$, decreasing $1.7 \%$ in the last 5 years. Italy registered the higher ELET rate $(14.5 \%)$ in spite of a decrease of $2.3 \%$. These rates justify the efforts developed in the STALWARTS to support the struggle against ELET by means of prevention, intervention and compensation measures (Council of the European Union, 2011) using arts-based pedagogical strategies, as we will see.

The Council of the European Union (2009) adopted the strategic framework for European cooperation in education and training-ET 2020-in May 2009. This strategic framework allows member states to cooperate in building best practice. It provides opportunities to gather and disseminate knowledge and seeks to advance national educational policy reforms. The prevention of ELET is based on the lifelong learning approach. It therefore addresses outcomes from early childhood to adult vocational and higher education and is designed to cover learning in all contexts: formal, non-formal and informal.

ET 2020 pursues the following four common EU objectives to:

- make lifelong learning and mobility a reality;

- improve the quality and efficiency of education and training; 


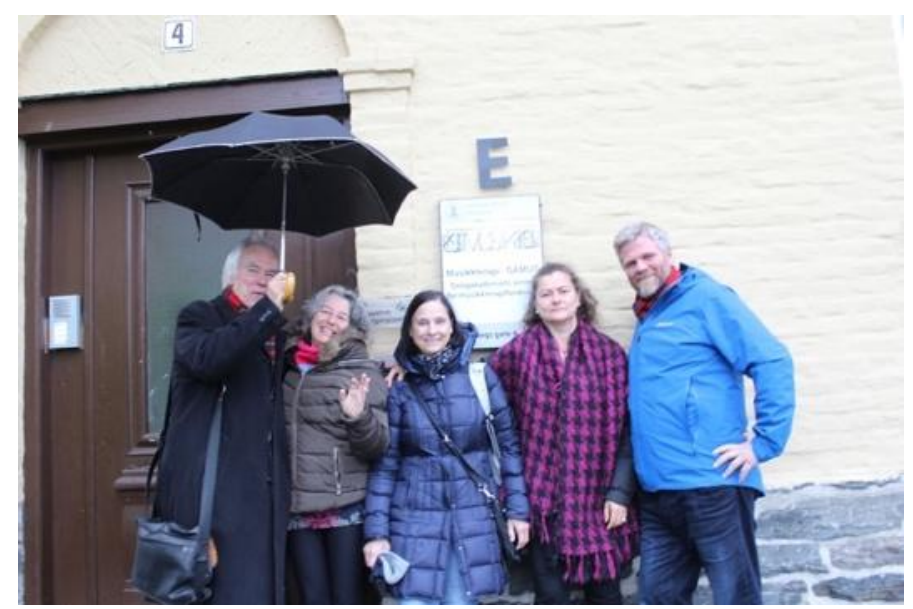

Figure 2

Bergen, Norway 31 October 2018: Meeting of the transnational project group: Leslie Bunt (project coordinator), Eunice Macedo, Eha Rüütel, Anna Rita Addessi and Viggo Krüger (from left to right), photo by Alexandra Carvalho

- promote equity, social cohesion and active citizenship; and

- enhance creativity and innovation, including entrepreneurship, at all levels of education and training (see Council of the European Union, 2009).

Funding by the Erasmus + programme, as provided to STALWARTS, is part of the means to achieve this ambition and these objectives.

In line with the recommendations of the Final Report of the Thematic Working Group on Early School Leaving (European Commission, 2013), the members of the STALWARTS project are aware that: 1) the quality of teaching and the competencies of the teachers are a determining factor in the contribution they can make to reducing ELET, 2) teachers and educators need the skills and abilities to work with other professions and partners to prevent ELET, 3) cooperation is particularly important in second chance education where learners often face multiple problems and require comprehensive support, and 4) cooperation needs to be centered on schools. Taking as a standpoint the benefits of mutual learning between education and care professions, STALWARTS was a cross-sectoral project that involved teams from a university and a school, working in close collaborative partnership within each country and amongst all.

\section{A top-down and bottom-up approach}

Making the best of their multiple scientific/artistic fields of expertise and areas of professional intervention, the STALWARTS project team used transnational project meetings to discuss how a combination of top down and bottom up reflection processes could inform the project. Based on existing policy documents on ELET, the members of the transnational project group (see photo) asked themselves, how could the STALWARTS partners in a best way contribute to solutions at a practice-based level, meeting the recommendations from a UN Committee on the Rights of the Child (UNCRC, 2014) and EU policy. The members studied policy documents valid for the ELET group and sought to encompass practice in line with various recommendations.

Therefore, the STALWARTS theoretical and methodological approach is based on UNCRC principles that encourage teachers and therapists to investigate the impact of sensory, relational and participatory aspects of music and the other arts. Project objectives aimed to create an articulated, practical and European response to the needs identified. In terms of the recovery from trauma by means of relational education with the arts the response includes the reengagement of young people in education within safe environments. Here they can develop as members of a group and have opportu- 
nities to (re)construct hopeful views of themselves in the present and with a view to their future education and employment.

By relating to these assumptions and intentions, the following sections focus on policy (UNCRC and relating to ELET), practice (at the institutional level including user involvement through Participatory Action Research [PAR] and the development of university modules), and theory including trauma-informed learning and attachment theory.

\section{Policy}

The Convention on the Rights of the Child (2014) was adopted by the UN in 1989. Most countries in the world have ratified the convention, apart from USA. UNCRC recognises that children not only are subjects of protection but also holders of civil and political rights. UNCRC defines a child as anyone below the age of 18 and affirms the child as fully covered by human rights. It contains 54 articles of children's rights that can be divided into three general categories, sometimes known as the three Ps (Hart, 1992):

Protection - guaranteeing the safety of children and covering specific issues such as abuse, neglect, and exploitation

Provision - covering the special needs of children such as education and health care

Participation - recognising the child's evolving capacity to make decisions and participate in society as they approach maturity

The following practical dimensions of the UNCRC are relevant for STALWARTS. They invite us to acknowledge that all children and adolescents are meaning-makers with the rights to be heard and to participate in society, regardless of factors such as gender, socio-political status, health, economy or geography. As such, the UNCRC invites discussion of ethical issues such as social inequality, potential asymmetrical power-relations between the child and adults in educational institutions and poverty. The UNCRC also stimulates reflection on when and how music and the arts are relevant as media in education.

However, research shows that there are barriers towards participation (Macedo \& Araújo, 2014). Including children as significant meaning-bearers seems to be one of the most difficult tasks in modern education society (Krüger, 2019, 2020). Professionals might fear damaging the health and care of the child and/or lacking communication competences and structures for facilitating participation (Munro, 2011).

\section{Practice}

Participatory Action Research (PAR) is a research paradigm within the social sciences which emphasises collaborative participation of trained researchers as well as local communities in producing knowledge directly relevant to the stakeholder community, leading to improvement in their life conditions. PAR is an inspiration for collecting and analysing data and the ways in which people engage in the theoretical-empirical work (Coghlan \& Brydon-Miller, 2014). Regarding STALWARTS, PAR had the potential to include teachers' and children's views in resourceful ways, using a range of methods such as drama, poetry, stories, music and visual arts (Pinter \& Zandian, 2015; Springgay, Irwin, \& Kind, 2008). The contemporary music therapy and education literature supports the use of participatory, collaborative and strengths-based approaches used in the STALWARTS project (Stige \& Aarø, 2012). Within community music therapy, a participatory approach acknowledges a willingness to listen to all voices in group processes, and to engage participants in a collaborative process of meaning-making. In this fashion, professionals and students

co-intent on reality, are both Subjects, not only in the task of unveiling that reality, and thereby coming to know it critically, but in the task of re-creating that knowledge. As 


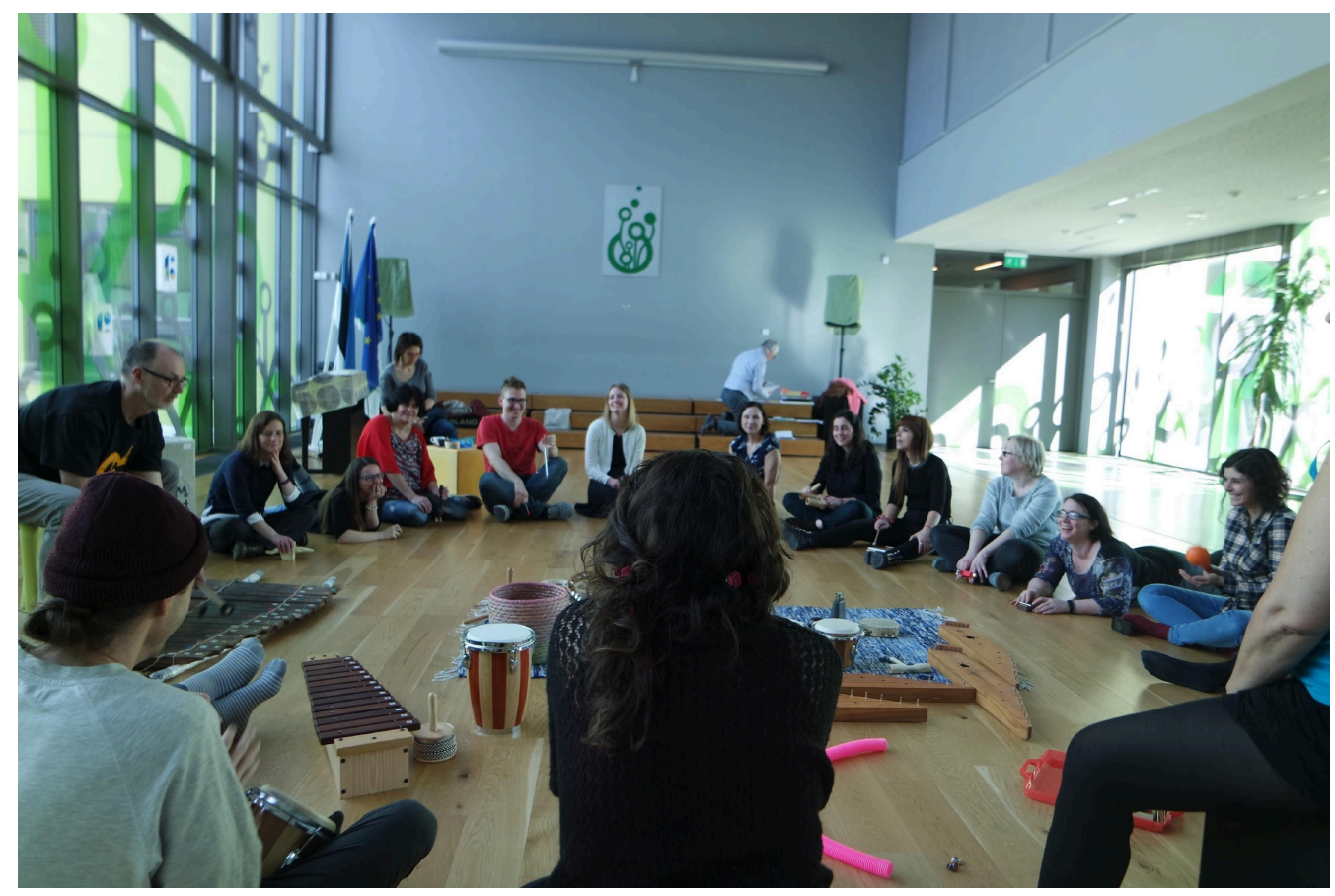

Figure 3

Tallinn, Estonia April 2018: Joint Staff Training Event (JSTE), photo by Viggo Krüger

they attain this knowledge of reality through common reflection and action, they discover themselves as its permanent re-creators. In this way, the presence of the oppressed in the struggle for their liberation will be what it should be: not pseudo-participation, but committed involvement (Freire, 2005, p. 69).

This co-intentionality aims to promote social change by collaborating with people in the community and providing access to resources and opportunities (Macedo \& Araújo, 2014) for musical engagement (Rolvsjord, 2010).

\section{STALWARTS partners' practice achievement}

From an Estonian perspective, STALWARTS brought to the inclusive partner, Randvere School, the international expertise of implementing music/arts in classroom. The project was embodied in mutual learning between trainers-researchers (based at Tallinn University), and teachers and students. The implementation of music was aided by the musical instrument box in the classroom, which was assembled for teachers. Through training, practice and the reflection of their experiences, teachers acquired the courage and skills to implement arts in a targeted way. Analysis of teachers' experiences revealed an importance of teacher's own attitudes towards the arts and three categories of functions of arts: inclusion of children in learning and school, developing children's general competencies, and supporting teachers' teaching strategies (Rüütel, Luik, \& Ratnik, 2020).

From an Italian point of view, teachers of the partner school, Istituto Comprensivo Granarolo dell' Emilia (ICGE), attended the modules at the University of Bologna organised within the project's framework, experimented with the musical activities proposed in the classrooms with the children, and finally produced small classroom-based enquiries, informed by neuroscientific knowledge in the first year and on the classroom activities in the second. ICGE teachers worked in collaboration with the Comune di Prato (Municipality of Prato, one of the project's associate partners) representing schools in the area around Prato in Tuscany. Furthermore, students attended the university modules led by musicians, music teachers and educators who implemented educational pathways or small-scale enquiries based on the use of music to support wellbeing and relational health in inclusive contexts (Addessi, 2019). The modules also in- 
volved the Children's Orchestra Quattrocanti of Palermo, another associate partner in STALWARTS and an organisation with social and inclusive commitments working in the neighborhood of Palermo with the highest percentage of immigration.

From a Norwegian perspective, the STALWARTS partner, Hyssingen Production School, developed activities where the goal was to learn from the students and teachers. As part of the project, a set of qualitative enquiries were conducted to learn from the activities carried out at the school. Researchers and creative therapists from the University of Bergen participated in four music workshops together with students and teachers at Hyssingen. By observing the activity and discussing with both teachers and students, the issues that were part of the shared reflections can be seen in relation to Key Competences of Lifelong Learning (Council Recommendation, 22 May 2018).

From a Portuguese point of view, there was a joint experience among educators and researchers (at the University of Porto) in the construction of practice-based enquiries at the community-based school, Escola de Segunda Oportunidade de Matosinhos (ESOM) a second chance school that has a focus on Art as experience. ${ }^{1}$ The performative character of learning seems to lead to greater school engagement, self-confidence and esteem (Macedo, Santos, \& Araújo, 2018; Macedo et al., 2017). The research process started with long-lasting participant observation. Together an action plan was defined that took into account the school concerns and the professionals' concerns about the real students in a real educational setting (Senge \& Scharmer, 2006). The team reflected upon observation of students and schoolwork, to define specific objectives for students, professionals and research. A set of classroom-based enquiries embodied the experience and reflection (Heron \& Reason, 2006), including the enquiries developed by Master's students from two curricular units on Educational Sciences, some of whom acted as co-researchers.

From a UK perspective, enquiries developed as a result of undertaking the modules developed at the University of the West of England, Bristol by educators at the partner school, Novalis Trust, that involved a range of age groups and different creative applications. The projects were typically neuroscience-informed in design and evaluation. They included initiatives as diverse as individual music sessions to strengthen school engagement and attendance, a play scheme for younger students and the use of yoga for staff and students together with family dyadic work involving trauma art and narrative therapy.

\section{The modules}

Each of the five university partners developed two university modules for continuing education related to ELET. The modules provided increased competence for teachers, musicians, therapists and other professionals who work with children and young people in contexts such as school and alternative learning organisations, child welfare, criminal justice and mental health. The modules included teaching topics for different groups in fields such as: music therapy theory and research, the neuroscience of music, music improvisation and creative composition, arts and dance education, music and inclusion, psychology, medicine, science theory and human rights, and educational and sociological approaches with relevance to ELET.

Emphasis was given to interdisciplinary discussions with the possibility of transferring competence to child welfare, child welfare pedagogy and social work. The modules provided experience and reflection on theory, ethics, law, practice and the understanding of social welfare systems. The modules, approved at the Master's level, were influenced by the students in the following way.

Trauma-informed learning: Several students emphasised the importance of a safe learning environment. As many come from difficult backgrounds, the school environment, staff, localities and resources provide the learner with stability and continuity towards wellbeing as a right.

Music and identity: Music has changed drastically during the last decades, and adults using music in ELET prevention need to be knowledgeable in themes related to music 
and identity. This is especially important in relation to genres such as Hip Hop (Guerra, 2017), EDM, black metal and K-pop.

Music and emotion regulation: A special factor in this field of study and practices is the relationship between emotions and music. In the setting of music therapy, as well in other creative practices, the analysis of emerged emotions needs to be integrated in a perspective that considers music as an element co-created by the partners in the creative relationship (Bunt \& Pavlicevic, 2001).

Inclusive education: Within the Europe 2020 Strategic Framework, inclusive education is the fundamental tool to overcome handicaps, disadvantages and marginalisation, to guarantee equity and promote the democratic principles of social cohesion, active citizenship and intercultural dialogue (Canevaro et al., 2011).

Ethics: The students gave valuable input on how to improve the student-teacher relationship. This includes themes such as power relations, relation development, students' sense of ownership, etc. One of the themes highlighted was the use of the term vulnerable young people. Some students were critical of how the term was used in the STALWARTS context, and they proposed alternatives such as competent young or resourceful young people.

\section{Further underpinning theoretical perspectives}

A returning theme for the STALWARTS project group was that if schools do not succeed in creating a culture for school wellbeing, individuals may face the danger of early school leaving (CEDEFOP, 2016). As ELET is a long-term process and the problems occur already in the early stages of education, attention to acquiring learning skills as early as possible is important. Hence, preschool and primary school are critical times in learning to learn.

\section{Attachment theory and neuroplasticity}

Creative arts therapies and related therapeutic and educational approaches in the STALWARTS project involve not only the use of language, but also non-verbal and preverbal approaches through self-expression such as music, dance or painting. For learners, non- and pre-verbal means of communication are an important part of any therapeutic and educational practice because participants do not always have the words and/or the will to convey feelings and experiences. It gives the child a second, alternative method and channel of communication (Rubin, 2005).

From a historical perspective, the human species has always included practices that provide healthy wellbeing (Habibi \& Damasio, 2014), such as holding each other, engaging in dance, song, image creation, and storytelling, and sharing celebrations and family rituals. This is confirmed by Perry (2008) who presented a neurodevelopmental perspective demonstrating how sensory-based experiences in early childhood are connected to how children enhance secure attachment, affiliation with others, empathy and self-regulation. A foundational basis for learning is safety and relation-building to support persons and role models. From attachment theory we can learn that non-verbal communication is our most basic form of communication and it is how caregiver and infant initially connect in those first years of life (Schore, 2003). Further, the field of attachment theory accepts that what happens early in life in terms of relationships impacts brain development and is essential to secure attachment (van der Kolk, 2014). In this perspective, neuroplasticity (or brain plasticity), is the ability of the brain to renew and, in some cases, rewire itself to compensate for deficits or damage. Brain plasticity is generally more accessible early in life, and supports the development of appropriate affect regulation, interpersonal skills, and cognition. In a relevant fashion for our purposes, it is worth noting that

advances in the neuroscience of emotions are highlighting connections between cognitive and emotional functions that have the potential to revolutionize our understanding of learning in the context of schools. (Immordino-Yang \& Damasio, 2007, p. 3) 


\section{The Role of Executive Brain Functioning in Creativity}

Wellbeing in school can be considered a context-sensitive concept that reflects the student's experience of feeling included, and the degree of adaptation the school environment is willing to facilitate for the pupil (Huebner et al., 2014). Consequently, school wellbeing includes the quality of student feelings such as joy and satisfaction, as well as experiences of opportunities, growth, development and social relations.

Following up on the previous theme, executive functions (EF) involve control processes such as goal-oriented planning, flexible strategy generation, sustaining set maintenance, self-monitoring, and inhibition. EF skills support learners to update ideas, shift between ideas, and inhibit irrelevant or stale ones. EF skills support a human being's organisation, creation of goals, focus on goal-oriented behaviors, judgement of importance and priorities, and achievement of steps leading to a resolution (Dawson \& Guare, 2010). EF skills take into account generation of multiple novel solutions to achieve goals or solve problems and that creativity emerges from the interface between cognition and emotions (Immordino-Yang \& Damasio, 2007). The EFs that support creativity include updating, shifting, and inhibition.

Updating can be described as a mental process of monitoring and revising what is done while completing a task. One decides to discard or replace obsolete information with more relevant one. This process takes information from working memory to support the individual in focusing on a given goal. Without updating, people start many tasks without completing them, or lose their focus while they are working. This sounds important to bringing creative ideas to fruition (Benedek et al., 2014).

Shifting involves switching between tasks, and controls what some people call multitasking. However, our brains cannot do more than one activity at once. Rather, they can shift back and forth between activities, albeit quickly. In addition to this, shifting involves some prioritisation as the brain disengages with tasks that are no longer relevant (Benedek et al., 2014).

Inhibition may foster creativity when creativity is looked at through divergent thinking tasks. Radel et al. (2015) found that if sense of inhibition is short before a task that involves creativity, the number of novel or creative ideas can increase. Some research suggests that a lack of inhibition could result in more creativity while it is also suggested that too little inhibition may make it difficult to stay focused on the goal (Benedek et al., 2014).

Integration of arts into leaning offers students more opportunities for higher-level thinking and allows them to process and demonstrate learning in creative ways (Green, Trundle, \& Shaheen, 2018). The connection between the EFs and learning is followed up in what has been labelled trauma-informed learning, and we will return to the connection between creativity and learning in the following sections.

\section{Trauma informed learning}

A recent example of knowledge-based practice integrating attachment theory and the value basis from the UNCRC is the perspective of trauma-informed learning (van der Kolk, 2014). The literature on trauma and resilience has produced long lists of risks and protective factors, but these can be distilled into a few fundamental principles (Nordanger \& Braarud, 2017). Bath (2015) postulated three pillars of trauma informed care. These three pillars of trauma-informed care, creating an environment that fosters healing and resilience, is also valid in school settings.

1. Safety entails an environment where one can feel secure, calm, and can attend to developmental tasks (Bath, 2015). As previously stated, management and self-regulation of emotions and memory play a role in this and teachers can contribute to students' safety experience by creating face-to-face dialogues where students are being met as equal partners in a working process. Talking about music and sharing stories or improvising with musical instruments creates a sense of trust and belonging, and may influence students' abilities to take part in school activities (see for example Hasler \& Hendry, 2017; Krüger, 2020). For some, even showing up at school may represent a 
huge challenge, and thus, to be met by caring adults who facilitate stability and predictability may be factors leading students to continue to attend school or not.

2. Connections involve trusting relationships with caring adults as well as normative community support such as music- and arts-based projects, sports teams, youth groups, and recreational programmes (Bath, 2015). Building connections fosters resilience by meeting growth needs for belonging and generosity. The teachers in the STALWARTS project have contributed in various ways to building connections as they share their creativity, professionalism, and personal stories. Teachers go beyond their traditional role, and act more like meaningful others and partners in production processes. Teachers also share interest with students as goals are achieved in a joint venture, such as sharing and co-writing poetry about emotions, feelings and daily life conditions (d'Abdon, 2016; Leggo, 2012).

3. Coping enables individuals to meet life challenges as well as to manage emotions and impulses underlying traumatic stress. In resilience terms, successful coping strengthens growth needs for mastery and independence (Bath, 2015). As such, the activities offered through STALWARTS may have different focuses. For example, improvisation, play or the making of a song can consist of many different tasks, and students can fill important roles and features in their own way. Students can practice roles as vocalists, musicians, actors, or technical assistants. In this way, participation in music and other expressive activities can contribute to the establishment of social networks and individual skills. The learning processes focus on the ability to learn how to learn in various ways, in line with Delors, $(1996,2013)$. The students take responsibility for their own learning, and they are encouraged to motivate other students. In collaboration, they set plans for learning, and this gives them important input in making the learning goals achievable, motivating and rewarding.

From the work within the STALWARTS project, a proposal for a fourth pillar emerges from engaging in Participatory Action Research where action and thinking came to play in fostering creativity as an important right (Hintz, 2017). Students' engagement with their own voices brings new meanings to the pillar of creativity.

4. Creativity. As we have learned from the young people and the teachers involved in the STALWARTS project, creativity includes a sense of initiative and entrepreneurship. Such experiences can support learners and communicate aspects of memories and stories that may not be readily available through conversation or speech alone. As such, creative arts in schools may provide a space for the support and development of basic cognitive processes that support creativity, such as the processes described above: updating, shifting and inhibition. From the perspective of attachment theory, research on the impact of trauma suggests that complex emotional experiences are encoded by the limbic system and right brain as sensory memories (van der Kolk, 2003). Therefore, sensory-based interventions drawing from creative arts-based therapies can be effective because they do not rely on the individual's use of left-brain language. Facilitating activities such as music and dance in a school setting may open up possibilities for right-brain language that otherwise would not be accessible for the student. On a social level, when students experience creativity through music and other arts-based activities, as in the case with the music workshops and classroom activities, they take part in collaborative partnership. Hence, learners engaged in accumulating processes of creative construction of artefacts such as songs, performances and recordings in a manner relevant for the arguments in this report. In fact, recently the topic of creativity has seen new perspectives of investigation within a constructivist and interactionist approach, where attention shifted from individual to collective and collaborative processes, underlining that collaborative creativity that can support and enhance the wellbeing experience of young people involved in musical groups (see, for example, Barrett, 2014; Bolger, Mcferran, \& Stige, 2018; Bunt, 2012; Burnard, 2012; Cross, Laurence, \& Rabinowitch, 2012; Odena, 2016; Schiavio \& Høffding, 2015). In previous studies, it was observed that collaborative music-making increases the flow emotional experience, the creative state of the human mind described by Csikszentmihalyi (1996), during collaborative playing (Addessi et al., 2015) and in the trauma-informed 
learning context (Tarr \& Addessi, 2017). Within the partnership in Norway, for example, students were responsible for the music workshop as described here.

The students are urged to elaborate on their cultural identity as a means for making music, recordings, films or performances. The use of Information Society Technology (IST) requires a critical and reflective attitude towards available information and a responsible use of technology and interactive media. An interest in engaging in communities and networks for cultural awareness and social expression purposes supports this competence. The students work with their own identity background as a basis for learning. This ensures that students gain ownership of their own learning processes and of the products made in a school setting (songs, recordings etc.).

\section{Final Remarks}

This report documents policy initiatives, practice and relevant theoretical contexts for STALWARTS. Regarding achievements, the project has brought to the partner schools international knowledge on how to implement music/arts-based activities in various classroom settings. The activities have been implemented based on a wish to support mutual learning between trainers and researchers, teachers and researchers, and students and researchers. The member countries also implemented two module training programmes at the Master's level.

Regarding policy initiatives, STALWARTS identified various documents spanning from the UNCRC level to the national and local levels. We have especially focused on national ELET documents, under the European law, and in which ways these can be seen regarding the prevention, intervention and compensation of school dropout. Each country has more or less structured national ELET strategies. Framed by common ELET European law, the singularities of these national strategies intertwine with the different educational and social settings of each partner. This diversity of contexts and professional fields in the project allowed developing intersubjectivity about arts-based practices for prevention (Italy and Estonia), intervention (United Kingdom) and compensation (Norway and Portugal) to support children and young people in their school pathways and in their present and future lives. We have identified political and theoretical perspectives relevant for the STALWARTS context, the UNCRC, attachment theory and neuroplasticity, the role of executive brain functioning in creativity, traumainformed care and lifelong learning. These perspectives are inter-related and underscore how the member countries in STALWARTS understand and reflect on the theme of ELET and arts-based education.

Summing up, what seems to be common in ELET measures in the five schools of the STALWARTS project can be highlighted as follows. First, the measure one wishes to introduce needs to be integrated into the school's other measures. Second, the measure needs to be tailored to the student's individual and collective needs and conditions. Third, the measure should not only target children in disadvantaged situations but include all children. Fourth, the measure needs to be established in such a way that the local community's resources are used. The factors mentioned here can be seen as ideals for the development of practice. Measures that integrate the factors into a common approach have a greater chance of success than measures that do not.

There were specific outcomes within each participant school and organisation. However, there are some continuities that can be highlighted. In general terms, organisations became more open-minded towards the introduction of music and arts-based activities and recognised the positive impact on their professionals and students. Many professionals took the risk to introduce change in their curriculum by introducing more open and communicative pedagogical devices and recognised the positive impact on their professional wellbeing as well as the wellbeing of the people with whom they work. Young people, in some cases, found a space to express their cultures and felt more relaxed attending school. In many cases, it can also be said that the benefits of the arts moved beyond the music or arts spaces in themselves to create a wider, safer and more interdependent environment where people worked together to learn with 
one another. More specifically, the participants (musicians, teachers, therapists, educators, and social workers) were able to develop technical-professional competences for using music and arts in inclusive contexts and with ELET commitments. They acquired new knowledge related to the communicative and inclusive potential of music, the neuroscientific evidence on the effects of music on brain processes, and elements of music therapy and arts therapies and their application in the field of inclusive education. They learned tools and strategies to observe, create, support and guide positive and inclusive musical interactions with children and young people while supporting and promoting their musicality, tools for observing and enhancing the flow experience and wellbeing through music, the fundaments of inclusive education (individualisation, personalisation, collaborative playing), and how to use musical experiences to promote inclusive processes.

Finally, as we have learned through the STALWARTS project, we would encourage abandoning the wait to fail model that is often practiced in schools. We need working models that can be recontextualised in diverse learning settings and where preventive measures are taken at an early level in order to prevent ELET. From an educational perspective, it can be argued that young people with a lack of school motivation, owing to their life conditions and the potential inadequacy of their schools, will need special support in a wide range of learning competencies and life skills. In order to participate in school and hence plan for their future education, we have to take into account that young students are competent and resourceful achievers of skills as seen in relation to many levels and subjects.

\section{Correction note}

The affiliation "NORCE Norwegian Research Centre, Norway" was added for author Viggo Krüger on 20.11.2020.

\section{Notes}

1. This title of the John Dewey's major book on aesthetics synthetically expresses daily life that ESOM tries to promote with few resources.

\section{References}

Addessi, A. R. (2019). Musical experience: An educational entitlement in inclusive contexts. The role of teachers/educators/social workers in promoting relational health. In T. Raptis \& D. Koniari (Eds.), Music education and society: New challenges, new orientations. Proceedings of the 8th Conference of the GSME (pp. 1-9). GSME.

Addessi, A. R., Ferrari, L., \& Carugati, F. (2015). The Flow Grid: A technique for observing and measuring emotional state in children interacting with a flow machine. Journal of New Music Research, 44(2), 129-144, https://doi.org/10.1080/09298215.2014.991738.

Araújo, H. C., Macedo, E., Santos, S. A., \& Doroftei, A. O. (2019). Tackling early school leaving: Principals' insights into Portuguese upper secondary schools. European Journal of Education, 54, 151-162, https://doi.org/10.1111/ejed.12328.

Barrett, M. S. (Ed.). (2014). Collaborative creative thought and practice in music. Ashgate Publishing.

Bath, H. (2015). The three pillars of traumawise care: Healing in the other 23 hours. Reclaiming Children and Youth, 23(4), 44-46.

Benedek, M., Jauk, E., Fink, A., Koschutnig, K., Reishofer, G., Ebner, F., \& Neubauer, A. (2014). To create or to recall? Neural mechanisms underlying the generation of creative new ideas. NeuroImage, 88, 125-133, https://doi.org/10.1016/j.neuroimage.2013.11.021.

Bolger, L., Mcferran, K., \& Stige, B. (2018). Hanging out and bullying in: Rethinking relationship building to avoid tokenism when striving for collaboration in music therapy. Music Therapy Perspectives, 36(2), https://doi.org/10.1093/mtp/miy002. 
Bunt, L., \& Pavlicevic, M. (2001). Music and emotion: Perspectives from music therapy. In P. N. Juslin \& J. Sloboda (Eds.), Music and emotion: Theory and research (pp. 181-201). Oxford University Press.

Bunt, L. (2012). Music therapy: A resource for creativity, health and well-being across the lifespan. In O. Odena (Ed.), Musical creativity: Insights from music education research (pp. 165-181). Ashgate Publishing.

Burnard, P. (2012). Commentary: Musical creativity as practice. In G. McPherson \& G. Welch (Eds.), The Oxford handbook of music education (pp. 319-336). Oxford University Press.

Canevaro, A., D Alonzo, L., Ianes, D., \& Caldin, R. (2011). L'integrazione scolastica nella percezione degli insegnanti [School integration in teachers' perceptions]. Erickson.

CEDEFOP. (2016). Leaving education early: putting vocational education and training centre stage: Vol. 2 Evaluating policy impact [CEDEFOP Research Paper \#58]. Luxembourg: Publications Office. https://doi.org/10.2801/967263.

Coghlan, D., \& Brydon-Miller, M. (2014). Participatory action research. In D. Coghlan \& M. Brydon-Miller (Eds.), The SAGE encyclopedia of action research (pp. 583-588). SAGE.

COM. (2011). Tackling early school leaving: A key contribution to the Europe 2020 Agenda. Communication from the Commission to the European Parliament, the Council, the European Economic and Social Committee and the Committee of the Regions. https://eur-lex.europa.eu/ LexUriServ/LexUriServ.do?uri= COM:2011:0018:FIN:EN:PDF.

Council of the European Union. (2009). Council conclusions of 12 May 2009 on a strategic framework for European cooperation in education and training (ET 2020). OJC, 119, 2-10, https://eur-lex.europa.eu/legal-content/EN/ALL/?uri = celex:52009XG0528(01).

Council of the European Union. (2011). Council Recommendation of 28 June 2011 on policies to reduce early school leaving. OJC, 191, https://eur-lex.europa.eu/LexUriServ/ LexUriServ.do?uri=OJ:C:2011:191:0001:0006:en:PDF.

Council Recommendation of 22 May 2018 on key competences for lifelong learning (ST/9009/ 2018/INIT). OJC, 189, 4.6.2018, 1-13. https://eur-lex.europa.eu/legal-content/EN/TXT/ $\mathrm{PDF} /$ ?uri $=$ CELEX:32018H0604(01)\&from $=\mathrm{EN}$

Cross, I., Laurence, F., \& Rabinowitch, T. C. (2012). Empathy and creativity in group musical practices: Towards a concept of empathic creativity. In G. McPherson \& G. Welch (Eds.), The Oxford handbook of music education (pp. 337-353). Oxford University Press.

d'Abdon, R. (2016). Teaching spoken word poetry as a tool for decolonizing and africanizing the South African curricula and implementing "literocracy.". Scrutiny2, 21(2), 44-62, https://doi.org/10.1080/18125441.2016.1192676.

Dawson, P., \& Guare, R. (2010). Executive skills in children and adolescents: A practical guide to assessment and intervention (2nd ed.). Guilford Press.

Delors, J. (1996). Learning: The treasure within. Report to UNESCO of the International Commission on Education for the Twenty-first Century. UNESCO Publishing. https://unesdoc.unesco.org/ ark:/48223/pf0000109590.

Delors, J. (2013). The treasure within: Learning to know, learning to do, learning to live together and learning to be. What is the value of that treasure 15 years after its publication? International Review of Education, 59, 319-330, https://doi.org/10.1007/s11159-013-9350-8.

Erasmus + . (2020). About Erasmus + . . . https://www.erasmusplus.org.uk/about-erasmus.

European Commission. (2011). Tackling early school leaving: A key contribution to the Europe 2020 Agenda. COM (2011), 18 Final, https://eur-lex.europa.eu/legal-content/EN/ $\mathrm{ALL} /$ ?uri $=$ CELEX:52011DC0018.

European Commission. (2013). Reducing early school leaving: Key messages and policy support. Final Report of the Thematic Working Group on Early School Leaving. European Commission. https://ec.europa.eu/education/sites/education/files/early-school-leavinggroup2013-report_en.pdf.

Eurostat. (2019). Early leavers from education and training. https://ec.europa.eu/eurostat/tgm/ refreshTableAction.do $\mathrm{tab}=$ table\&plugin $=1 \&$ pcode $=$ t2020_40\&language $=$ en. 
Felitti, V. J., \& Anda, R. F. (2010). The relationship of adverse childhood experiences to adult medical disease, psychiatric disorders, and sexual behavior: Implications for healthcare. In R. Lanius \& E. Vermette (Eds.), The hidden epidemic: The impact of early life trauma on health and disease (pp. 77-87). Cambridge University Press.

Freire, P. (2005). Pedagogy of the oppressed (30th anniversary edition). Continuum.

Green, K., Trundle, K. C., \& Shaheen, M. (2018). Integrating the arts into science teaching and learning: A literature review. Journal for Learning through the Arts, 14(1), https://doi.org/ 10.21977/D914140829.

Guerra, P. (2017). Capicua e Bourdieu: Entre o RAP e a sociologia [Capicua and Bourdieu: Between RAP and sociology]. https://repositorio-aberto.up.pt/bitstream/10216/104342/2/ 193865.pdf.

Habibi, A., \& Damasio, A. (2014). Music, feelings, and the human brain. Psychomusicology: Music, Mind, and Brain, 24(1), 92-102, https://doi.org/, https://psycnet.apa.org/doi/ $10.1037 / \mathrm{pmu} 0000033$.

Hart, R. (1992). Children's participation from tokenism to citizenship. UNICEF Innocenti Research Centre.

Hasler, J., \& Hendry, A. (2017). Creative therapies for complex trauma: Helping children and families in foster care, kinship care of adoption. Jessica Kingsley Publications.

Heron, J., \& Reason, P. (2006). The practice of co-operative inquiry: Research 'with' rather than 'on' people. In P. Reason \& H. Bradbury (Eds.), Handbook of action research (pp. 144-154). Sage.

Hintz, L. D. (2017). The ethics of art therapy: Promoting creativity as a force for positive change. Art Therapy, 34(3), 142-145, https://doi.org/10.1080/07421656.2017.1343073.

Huebner, E. S., Hills, K. J., Siddall, J., \& Gilman, R. (2014). Life satisfaction and schooling: Handbook of positive psychology in the schools. Routledge.

Immordino-Yang, M. H., \& Damasio, A. (2007). We feel, therefore we learn: The relevance of affective and social neuroscience to education. Mind, Brain, and Education, 1(310), https://doi.org/10.1111/j.1751-228X.2007.00004.x.

Kallip, K., \& Heidmets, M. (2017). Varakult haridussüsteemist lahkumine: trendid, mõjurid ja meetmed Eestis. [Early leaving from education and training: Trends, factors and measures in Estonia]. Eesti Haridusteaduste Ajakiri, 5(2), 155-182, https://doi.org/10.12697/ eha.2017.5.2.07.

Krüger, V. (2020). Music therapy in child welfare: Bridging provision, protection and participation. Barcelona Publishers.

Krüger, V. (2019). Music as a structuring resource in identity formation processes by adolescents engaging in music therapy-A case story from a Norwegian child welfare setting. In K. McFerran, P. Derrington, \& S. Saarikallio (Eds.), Handbook of music, adolescents, and wellbeing (pp. 127-138). Oxford University Press.

Kunnskapsdepartmentet. (2020). Ny giv. https://www.regjeringen.no/globalassets/upload/kd/ kampanjer/nygiv/presentasjoner/samarbeid_om_oppfolging_av_ungdom.pdf.

Leggo, C. (2012). Living language: What is a poem good for? Journal of the Canadian Association for Curriculum Studies, 10, 141-160.

Macedo, E., Santos, S. A., Torres, F., \& Hardalova, P. (2017). Reinventing the allegory of the cave through drama: Teachers' challenges and competences in education. Educação, Sociedade \& Culturas, 50, 75-93, https://www.fpce.up.pt/ciie/sites/default/files/ ESC50_Eunice_etal.pdf.

Macedo, E., \& Araújo, H. C. (2014). Young Portuguese construction of educational citizenship: Commitments and conflicts in semi-disadvantaged secondary schools. Journal of Youth Studies, 17(3), 343-359, https://doi.org/10.1080/13676261.2013.825707.

Macedo, E., Santos, S. A., \& Araújo, H. C. (2018). How can a second chance school support young adults' transition back to education? European Journal of Education, 53, 452-455, https://doi.org/10.1111/ejed.12312. 
MIUR-Ministero dell'Istruzione dell'Università e della Ricerca . (2010). Legge n.170/2010 [Law n. 170/2010]. https://www.gazzettaufficiale.it/gunewsletter/ dettaglio.jsp? service $=1 \&$ datagu $=2010$.

MIUR. (2011). Decreto ministeriale n. 5669/2011 [Ministerial decree n. 5669/2011]. https://www.istruzione.it/esame_di_stato/Primo_Ciclo/normativa/allegati/prot5669_11.pdf.

MIUR. (2012). DIRETTIVA-27/12/2012, Strumenti d'intervento per alunni con bisogni educativi speciali e organizzazione territoriale per l'inclusione scolastica [Intervention tools for pupils with special educational needs and territorial organization for school inclusion]. https://www.miur.gov.it/documents/20182/0/ Direttiva + Ministeriale + 27 + Dicembre + 2012.pdf/e1ee3673-cf97-441cb14d-7ae5f386c78c?version $=1.1 \& \mathrm{t}=1496144766837$.

MIUR-Ministero dell'Educazione dell'Università e della Ricerca . (2018). Una politica nazionale di contrasto del fallimento formativo e della povertà educative [A national policy to combat educational failure and educational poverty]. http://www.miur.gov.it/documents/20182/0/ Rapporto + sul + contrasto + del + fallimento + formativo/7575f155-63f9-479aa77f-1 da743492e92?version $=1.0$.

Munro, E. (2011). Munro review of child protection, final report: A child-centred system.

Nordanger, D., \& Braarud, H. C. (2017). Utviklingstraumer: Regulering som nøkkelbegrep i en ny traumepsykologi [Developmental trauma: Regulation as a key concept in a new trauma psychology]. Fagbokforlaget.

Odena, O. (Ed.). (2016). Musical creativity: Insight from music education research. Taylor \& Francis.

Office for National Statistics. (2020). Young People not in Education, Employment or Training. https://www.ons.gov.uk/employmentandlabourmarket/peoplenotinwork/uemployment/ datasets/youngpeoplenotineducationemploymentortrainingneettable1.

Perry, B. (2008). Foreword. In C. Malchiodi (Ed.), Creative interventions with traumatized children. Guilford Press.

Pinter, A., \& Zandian, S. (2015). "I thought it would be tiny little one phrase that we said, in a huge big pile of papers": Children's reflections on their involvement in participatory research. Qualitative Research, 15(2), 235-250.

Radel, R., Davranche, K., Fournier, M., \& Dietrich, A. (2015). The role of (dis)inhibition in creativity: Decreased inhibition improves idea generation. Cognition, 134, 110-120, https://doi.org/10.1016/j.cognition.2014.09.001.

República Portuguesa. (2017). Estratégia Nacional de Educação para a Cidadania [National Strategy for Citizenship Education]. http://www.dge.mec.pt/sites/default/files/ Projetos_Curriculares/Aprendizagens_Essenciais/estrategia_cidadania_original.pdf.

Rolvsjord, R. (2010). Resource-oriented music therapy in mental health care. Barcelona Publishers.

Rubin, J. A. (2005). Child art therapy (25th anniversary ed.). John Wiley \& Sons.

Rüütel, E., Luik, M., \& Ratnik, M. (2020). Musical activities as a tool for a class teacher to include students in a school lesson. CFMAE - Changing Face of Music and Art Education, 10, 107-122.

Schiavio, A., \& Høffding, S. (2015). Playing together without communicating? A pre reflective and enactive account of joint musical performance. Musicae Scientiae, 19, 366-388, https://doi.org/10.1177\%2F1029864915593333.

Schore, A. (2003). Affect regulation and the repair of the self. Norton.

Senge, P., \& Scharmer, C. (2006). Community action-research: Learning as a community of practitioners, consultants and researchers. In P. Reason \& H. Bradbury (Eds.), Handbook of action-research (pp. 195-206). Sage.

Springgay, S., Irwin, R. L., \& Kind, S. (2008). A/R/Tographers and living inquiry. In J. G. Knowles \& A. L. Cole (Eds.), Handbook of the arts in qualitative research: Perspectives, methodologies, examples and issues (pp. 83-91). Sage. 
Stige, B., \& Aarø, L. E. (2012). Invitation to community music therapy. Routledge.

Tarr, J., \& Addessi, A. R. (2017). Preparing to observe the impact of therapeutic teaching practices. From Flow to self regulation and learning. Educação, Sociedade \& Culturas, 50, 95-116.

UN Committee on the Rights of the Child. (2014). Concluding observations on the combined third and fourth periodic report of Portugal (CRC/C/PRT/3-4). https://www.refworld.org/docid/ 52f89eb84.html.

van der Kolk, B. (2003). The neurobiology of childhood trauma and abuse. Child and Adolescent Psychiatric Clinics of North America, 12(2), 293-317, https://doi.org/10.1111/ j.1365-2206.2007.00527.x.

van der Kolk, B. (2014). The body keeps the score: Brain, mind, and body in the healing of trauma. Viking Press.

Vinnerljung, B., \& Sallnäs, M. (2008). Into adulthood: A follow-up study of 718 young people who were placed in out-of-home care during their teens. Child and Family Social Work, 13, 144-155, https://doi.org/10.1111/j.1365-2206.2007.00527.x.

\section{Appendix - Understanding the national positions on ELET}

This section provides a brief overview of how the different countries are dealing with ELET in order to understand similarities and differences between national strategies.

In Estonia, Kallip and Heidmets (2017) analysed the measures for tackling or contributing to reducing ELET and pointed out that there is no comprehensive ELET strategy in Estonia. They highlight the preventive measures implemented at the state, local and school level, e.g. improving access to high quality childhood education and care; widely implemented education and career guidance systems at different educational levels; thoroughly addressing the topics of ELET in teachers' training; and increasing the preparation of support specialists for schools.

The Italian Ministry of Education recommended developing an integrated plan among the schools and the territorial institutions (MIUR, 2018). The Italian legislation (MIUR, 2010, 2011, 2012) specified the inclusive strategies by extending the intervention of the educational community to the full area of Special Educational Needs (BES), including social and cultural disadvantage, specific learning and developmental disorders. The strategies of individualisation and personalisation represent the privileged measures for defining, monitoring and documenting the most suitable process of intervention, according to a collegial, co-responsible and participatory procedure of the schools. The territorial institutions support the inclusive process, the professional development of teachers and the dissemination of best practices.

Norway has assigned a strategy called New Possibilities (in Norwegian Ny giv [Ny Giv - Oppfølgingsprosjektet - samarbeid om oppfølging av ungdom]; Kunnskapsdepartementet, 2020). The target group for the national strategy is adolescents not in education, employment, or training (NEET) between the ages of 16 and 21. The Norwegian national strategy aims to increase the successful completion rate for upper secondary education and training from $70 \%$ to $75 \%$. The main goal is to improve the cooperation between different levels of government and between different measures. The project is nationwide and several measures have been implemented to accomplish the goal of increased completion in upper secondary education and training.

In Portugal, the National Strategy for Citizenship Education in schools 2017/2018 focuses on participation, one of the three Ps of the UN Convention on the Rights of the Child Convention (see below), ensuring children and young people's democratic citizenship through education, equality in interpersonal relationships, recognition of differences and respect for human rights (República Portuguesa, 2017). The impacts of the recession on families and public social investment increased the risk of poverty and diminished access to health, education and social protection. Numerous legislative measures have been adopted, such as the extension of compulsory education up to grade 12 or 18 years old, with ELET as a core concern, stressing the need to reinforce 
social investment and protection of "those in the most vulnerable situations ( ... ) giving priority to children" (UN Committee on the Rights of the Child, 2014, p. 3).

In the United Kingdom, the phrase not in education, employment or training (NEET) is used rather than ELET, which currently describes $11 \%$ of young people (Office for National Statistics, 2020). The primary UK strategy to tackle NEET is Building Engagement, Building Futures: Our Strategy to Maximise the Participation of 16-24 Year Olds in Education, Training and Work (2011). This raised the age until which young people were required to stay in education or training to 17 (2013), and then 18 (2015), improving quality and quantity of apprenticeships, vocational education and career advice for young people. 